\title{
EXPLORING THE LINKAGES BETWEEN DEMING'S PRINCIPLE, WORLD-CLASS COMPANY, OPERATIONAL EXCELLENCE, AND COMPANY PERFORMANCE IN AN OIL AND GAS INDUSTRY SETTING*
}

\author{
WakhidSlamet Ciptono
}

This study explores the linkages between Deming's Principle, World-Class Company, Operational Excellence, and Company Performance in the Indonesia's oil and gas industry. The aim of this study is to examine the causal relationships model between the Deming's Principle (DP), World-Class Company (WCC), Operational Excellence (OE), and Company Performance (Monetary Gain Performance or MGP and Value Gain Performance or VGP). The author used 140 strategic business units (SBUs) in 49 oil and gas companies in Indonesia. The survey was administered to every level of management at each SBU (Top, Middle, and Low Level Management). A multiple informant sampling unit is used to ensure a balanced viewof the relationships between the research constructs, and to collect data from the most informed respondents on different levels of management. A total of 1,332 individual usable questionnaires were returned thus qualified for analysis, representing an effectiveresponserate of 50.19 percent.

Path analysis and structural equation modeling (SEM) are used to analyze the effect of Deming 's principle on company performance

\footnotetext{
* Acknowledgements:

The author would like to acknowledge the work of three supervisors-Assoc. Prof. Dr. Abdul Razak Ibrahim, Assoc. Prof. Dr. Ainin Sulaiman, and Assoc. Prof. Dr. Tan Lee Peng and two anonymous referees. Their advices and constructive comments on an earlier draft of this paper resulted in significant changes and improvements. I am thankful for their dedication to the field devotion to helping others. "Promote the good and prevent the bad."
} 
Gadjah Mada International Journal of Business, May-August 2005, Vol. 7, No. 2

and to investigate the interrelationships between Deming 's principle, world-class company, operational excellence, and company performance. The results show that Deming's Principle has significant positive and indirect effect on company performance (monetary gain performance and value gain performance). Although the Deming's Principle has no significant direct effects on company performance, the Deming's Principle has significant positive effects on the intervening variables (world-class company and operational excellence). The result also shows that a complete model fit and the acceptable parameter level that indicate the overall parameter are good fit between the hypothesized model and the observed data. By concentrating on a single industry (oil and gas), SEM specification of the causal relationship model between five constructs can be more complete and specific because unique characteristics of the oil and gas industry can be included (upstream and downstream chain activities). Finally, the particular design of the research and the findings suggest that the structural model of the study has a great potential for replication to manufacturing as well as service operations.

Keywords: company performance; Deming's principles; operationalexcellence; worldclass company

\section{Introduction}

Total quality management (TQM) as articulated by the quality management gurus — such as Juran (1994), Ishikawa (1985), Deming (1986), and Crosby (1989) - is a set of powerful interventions wrapped in a highly attractive package. When implemented well, TQM can help an organization improves itself and, in the process, better serves its community and its own stakeholders (Hackman and Wageman 1995). Researchers like Imai (1986) Usilaner(1992), Shetty (1993), Smith and Sibler (1994), Krumwiede et al. (1996), and Shin et al. (1998) suggested that top management plays such a key role in establishing and maintaining any type of corporate culture, its leadership behavior and personality become critical to successful implementation of the TQM philosophy.

The characteristic of successful TQMimplementation program encourages organizations to address quality on a broad range of issues (i.e., worldclass standards, operational excellence, and company performance). Not all of the implementations of TQM have been successful as expected. Researchers like Harari (1993; 1997), Becker (1993), Russel(1993), Usilaner(1992), Eskildson (1994), Kolesar (1995), Krumwiede et al. (1996), Tatikonda 
Ciptono-Exploring the Linkages between Deming's Principle, World-Class Company,...

and Tatikonda (1996) and Anderson et al. (1998), suggested that TQM is failing at a rate of two out of three.

Based on the lessons from successful and unsuccessful TQM implementations that have already been done by worldwide organizations in the past two decades, Hackman and Wageman (1995) stated that the challenge in research on TQM is to specify and collect data about those processes that would be expected to result from TQM and that should, all else being equal, contribute to company performance. The major emphasis of this study is on an empirical research orientation of the development of the causal relationship of Deming's principle, worldclass company, operational excellence, and company performance in the Indonesia's oil and gas industry. This research orientation is consistent with the fact that TQM is still recognized only recently by companies as a powerful competitive strategy in order to achieve world-class company successfully (Madu and Kuei 1993 in Ahire et al. 1995).

Indonesia's oil and gas companies realize that they must make some very fundamental changes to compete in unpredictable oil and gas market. With substantial reserves of natural gas, coal and geothermal, Indonesia could remain as a net energy exporter for a longer period than current forecasts (Embassy of the USA 2004). To do so, the government has implemented legislation and policies that will attract new private direct investment and rationalize use of Indonesia's energy resources (i.e. oil and gas). Energy policy reform is necessary in order to maintain Indonesia's status as a net oil and gas exporter and enhance efficient usage of energy resources.

In addition, the Indonesian Parliament passed the oil and gas bill into the new law concerning oil and gas on October 23, 2001. The new law (Law of the Republic of Indonesia number 22/2001) authorizes the establishment of an implementation agency for oil and gas upstream operations and a downstream regulatory agency to assume state oil and gas company's roles. The implementation agency has replaced the state oil and gas company in managing Production Sharing Contract (PSC) with private oil and gas companies. The new law also removed the state oil and company's monopoly in the downstream sector with the regulatory agency assuming the responsibility for managing natural gas and domestic fuel distribution and supply (Embassy of the USA 2004; Law of the Republic of Indonesia number 22/ 2001).

In order, to meet the future challenges of discovering new reserves, the oil and gas companies have restructured their companies into a Strategic Business Unit (SBU) organization towards achieving the world-class vision (to be recognized as world-class companies committed to operational excellence). The SBUs have already implemented TQM program to achieve this vision. Although TQM program had been, and will continue to be vital part of companies' operations, compa- 
Gadjah Mada International Journal of Business, May-August 2005, Vol. 7, No. 2

nies must fundamentally rethink their ways of conducting business and have the courage to implement Deming's principle where necessary to achieve the real changes in company performance (monetary gain and value gain performances) through world-class company and operational excellence.

The rest of this paper is organized as follows. The next sections of this study discuss objectives of the study, related literature and asses TQM practices, review of methodology, and interpretation of results. The conclusions and contributions are provided at the last session.

\section{Objectives of the Study}

To validate the oil and companies' claim to TQM practices, the causal relationships of Deming's principle, world-class company, operational excellence, and company performance have been developed through this study. In light of these research constructs, the objectives for this study are twofold:

(1) To develop a path analytical framework or structural equation model which includes the interrelationships between five research constructs: Deming's principles as the independent variable, world-class company, and operational excellence constructs as the mediating variables and further, the importance of considering two distinct types of company performance (monetary gain performance and value gain performance) as the dependent variables;
(2) To establish the relationships among five research constructs that are both substantively meaningful and statistically well-fitting for the Indonesia's oil and gas industry in order to fulfill its vision to berecognized as World-Class Company committed to operational excellence based on the oil and gas policy reform.

A testable model in this study would be beneficial to conduct an empirical study that more systematically investigates the extent to which TQM practices (based on Deming's Principle) and success as connections of differing contemporary management practices, such as world-class company, operational excellence, and company performance. Such study could be done not only within the same industry, but also across different firms and different industries. The research could verify, or refute, a testable model in this study might suggest more precisely how Deming's Principle vary depending upon the other change initiatives or situational variables. The approach of the study is to conduct empirical research guided by existing theories.

\section{Related Literature and Assessing TQM Practices}

According to Hackman and Wageman (1995), a full-fledged evaluation of a TQM program would include three distinct type of assessment. First is empirical study that TQM actually has been implemented. Sec- 
Ciptono-Exploring the Linkages between Deming's Principle, World-Class Company,...

ond is determination of whether TQM alters the degree to which the improvements in organizational functions that are expected actually are observed. Third comes assessment of the degree to which improvements in bottom-line organizational effectiveness are found. It is important to examine both process (Deming's principle, world-class company, operational excellence) and outcome criteria (company performance) in measuring and assessing TQM practices. In addition, empirical evaluation of TQM program presents a significant challenge to researchers because what must be done to accomplish the three assessments involves very different methods and analytical strategies.

To assess how TQM is actually practiced in the Indonesia's oil and gas industry, the author addresses two questions. First, in what ways are contemporary implementations of TQM consistent with the founder's tenets (Deming's principle)? Second, in what ways do current practices differ from the Deming's prescriptions, and do those differences enrich the core ideas of TQM or diverge from them? Answering the two questions will contribute to a deeper understanding of the relationship between the role of each of the elements of TQM (Deming's principles) and company performance. This would help managers with the allocation of resources to those categories that have the most significant effect on company performance (Samson and Terziovski 1999). Samson and Terziovski stated that only a small percentage of over 1000 articles on the TQM philosophy and methods attempted to test the strength of the relationship between TQM and company performance.

In addition, attempts are needed to realize that TQM practices need not to operate in isolation from other change initiative programs, such as operational excellence and world-class company - it could be integrated. This study investigates the rational of linkage (a marriage) between five constructs (Deming's Principles, worldclass company, operational excellence, and two distinct types of company performance - monetary and value gains performance). Dave and Buschmann (1998) stated the goal of world-class company and operational excellence is to reduce total operating costs, to improve productivity in an already well-understood critical success factors such as critical success factors of TQM implementation, and to enable previously unavailable worldclass strategic capabilities. Successful TQM implementation model (based on Deming's Principle) should consider the other contemporary management such as World-Class Company, Operational Excellence, and Company Performance as an integrated network (connections) management system. The study wants to determine that with connections, TQM practices could be repositioned as a more impactive business improvement program. As a further effort to renew interest in TQM practices, all SBUs along the supply and demand $\square$ - chains in the oil and gas 
Gadjah Mada International Journal of Business, May-August 2005, Vol. 7, No. 2

industry begin to realize that they depended on each other and that poor quality from one SBU partner mushroomed to affect others.

A number of research studies of TQM and quality award systems have been conducted, and led to a debate about the effectiveness of such awards and of the various TQM elements. These studies have been either perceptual studies or small-scale empirical works (Samson and Terziovski 1999). The present study is a large cross-sectional examination of 140 SBUs in oil and gas companies with 1332 respondents (multiple informant). In this section the author examines some of the key existing empirical studies.

Tamimi (1998) in his study of a second-order factor analysis of critical TQM factors stated that the effective transformation to the total quality management (TQM) organization has been linked to the extent to which firms successfully implement certain critical TQM practices. Tamimi (1998) developed a second-order factor model to test whether a set of critical quality management factors load on an overall construct that may be termed Total Quality Management. Using survey data collected from 173 manufacturing and service firms, the LISREL VII computer program is used to estimate and validate the proposed model. The results provide the eight factors collectively load on a single factor called TQM. The eight critical factors of TQM were top management commitment, supervisory leadership, education, cross-functional communications to improve quality, supplier management, quality training, product/service innovation, and providing assurance for employees.

Saraph et al. (1989) provided a synthesis of the quality literature by identifying eight critical factors of quality management in a business unit. The eight critical factors of quality management based on Saraph et al. (1989) are: the role of management leadership and quality policy, role of the quality department, training, product/service design, supplier quality management, process management, quality data and reporting, and employee relations. Operational measures of these factors are developed using data collected from 162 general managers and quality managers of 89 business units or 20 companies. Researchers can use such measures to better understand quality management practice and to build theories and models that relate the critical factors of quality management to the organization's quality environment and quality performance.

Black and Porter (1996) extracted a series of items from the Baldrige Model and established literature. These items formed the basis of a questionnaire sent to over 200 managers. Data was examined using several well-established analytical techniques that identified 10 critical factors of TQM. These ten critical factors were people and customer management, supplier partnership, communication of improvement information, customer satisfaction orientation, external interface management, strategic quality man- 
Ciptono-Exploring the Linkages between Deming's Principle, World-Class Company,...

agement, teamwork structures for improvement, operational quality planning, quality improvement measurement systems, and corporate quality culture. The findings can be used to improve existing self-assessment frameworks such as the Baldrige and European Quality Award criteria.

Samson and Terziovski (1999) examined the TQM practices and operational performance of a large number of manufacturing companies (1200 companies) in Australia and New Zealand in order to determine the relationships between these practices, individually and collectively, and firm performance. The study showed that the relationship between TQM practice (leadership, management of people, and customer focus) and organizational operational performance is significant in a cross-sectional sense.

Antony et al. (2002) provided an empirical study on the identification of the critical success factors (CSFs of TQM) implementation in Hong Kong industries. Through a thorough and detailed analysis of the literature, 11 success factors with 72 elements were identified to develop a questionnaire. These items were empirically tested by data collected from 32 companies in Hong Kong. A factor analysis was carried out and identified seven CSFs with 38 elements of the implementation of TQM. These CSFs were training and education, quality data and reporting, management commitment, customer satisfaction orientation, role of the quality department, communication to improve quality, and continuous improvement.
From the above key existing empirical studies of critical success factors of TQM, there is certainly not a clear agreement as to what the "real" factors of TQM are, and there will always the disagreements as to 'how to best cut the TQM cake' into factors or elements (Samson and Terziovski 1999). Nothing that the differences exist and are generally not major, the author prefers to use a well established factor set, the Deming's 14 points, and move on to test the correspondence of these factors, individually and collectively, with world-class company, operational excellence and company performance measures, which is an additional step from Tamimi's contribution.

The author's motivation is based on wishing to contribute to knowledge about 'What works?' This means using not only methods similar to those of Saraph et al. (1989), Black and Porter (1996), Tamimi (1998), and Samson and Teziovski (1999) but also using matched world-class company, operational excellence, and company performance, to test linkages of the established Deming's principles to company performance through worldclass company and operational excellence.

\section{Review of Methodology}

\section{Population and Sampling}

The Indonesia's oil and gas industry is an oil and gas industry consisting of seven independent group companies based on the contract types: State- 
Gadjah Mada International Journal of Business, May-August 2005, Vol. 7, No. 2

Owned Company, Production Sharing Contract (PSC) Onshore, PSC Offshore, Joint Operating Body (JOB) Onshore, JOB Offshore, Technical Assistance Contract (TAC) Onshore, TAC Offshore (based on the new law of oil and gas number 22/2001). This industry contains 60 oil and gas companies and 200 strategic business units (SBUs). This oil and gas industry was selected because it has been a leader in implementing progressive quality management strategies in Indonesia (Hakim 1996).

The primary unit of analysis for empirical validation is the individual Strategic Business Unit (SBU) level. The SBU organizational structure is chosen in this study because of three reasons. First, the Indonesia's oil and gas companies have realized that SBUs allow corporate management to delegate authority for the strategic management of distinct business entities - the SBUs (Hakim 1996; Pearce and Robinson 2005). In addition the SBUs are profit centers, which facilitates accurate assessment of profit and loss. The second important reason of choosing the SBU as unit of analysis is that the advantage of the SBU to meet the increased coordination and decisionmaking requirements that result from increased diversity and size (Pearce and Robinson 2005). Third, the SBU is the level of implementation for most quality management program. Furthermore, studies have shown (e.g. Saraph et al. 1989) that quality investments vary between plants or SBUs within the same firm, indicating that a more aggregated unit of analysis, such as the parent firm level, would likely obscure important differences (Curkovic 2000 et al.).

Two thousand and eight hundred (2800) questionnaires were distributed to the participating (49) oil and gas companies in a qualified sample of 140 SBUs. Each qualified sample of 140 SBUs from 49 oil and gas companies received 20 questionnaires. The survey was administered to every level of manager (top, middle, low levels or multiple informant) of oil and gas companies at the SBU level. Only responses that answered completely on of the research constructs were used.

An assessment of non response bias was made by using the extrapolation approach recommended by Armstrong (1979). Tests revealed no significant differences between early responders (the first wave of responses; $\mathrm{n}=442$ ) and late responders (the second wave of responses; $n=890$ ) on any of the constructs.

In terms of number of cases (SBUs), some people argued the minimum cases to run structural equation analysis was 200 and/or ten times the number of observed variables in the most complex construct. However, the recent article by Gefen et al. (2000) demonstrated that the required minimum sample size was around 100-150 cases (SBUs). Thus, this study with 140 cases (a qualified of 140 SBUs) was considered appropriate to run the AMOS program (Achjari and Quaddus 2004). 
Ciptono-Exploring the Linkages between Deming's Principle, World-Class Company,...

\section{Choice of Research Method}

According to Yin (2003), there are three conditions that determine the applicability of certain research strategies. The three conditions consist of (1) the type of research question posed, (2) the extent of control an investigator has over actual behavioral events, and (3) the degree of focus on contemporary as apposed to historical events. Yin suggests that various strategies are not mutually exclusive, but that certain situations exist in which a specific strategy has a distinct advantage. For the case study approach (i.e. a single industry and/or multiple case study) to have a distinct advantage, a "how" and "why" questions (an explanatory research approach) should be asked about a contemporary set of events over which the investigator has little or no control. Smith and Reece (1999) used this criterion in their article of the relationship of strategy, fit, productivity, and business performance in a service setting.

The particulars of this study, in terms of the condition suggested by Yin (2003) and implemented by Smith and Reece (1999), strongly suggest the case study (a single industry and/or multiple case study) as the most appropriate research methodology. A single industry was chosen for the study because the restriction permitted the control of several potential confounding variables that often differ between industries, including the scope and complexity of quality issues (Curkovic et al. 2000). The most important contribution of the present investigation (the causal relationships) is in the analysis of a sample of companies at the strategic business units (SBUs) level from the same industry (a single industry oil and gas industry). The advantage of concentrating on a single industry is that the structural equation model (SEM) of the relationships between five research constructs can be more complete because unique characteristics of the industry can be included (Simpson and Kohers 2002).

\section{Data Collection Methods}

Empirical data for the cross-sectional study was collected from Indonesia's oil and gas companies under Directorate of oil and gas's contract system and procedure. Many decision contexts using cross-sectional analysis compare entities that are "similar" in at least one attribute. The study considered the following alternative approaches to define "similar" entities (Foster 1998): similarity on supplyside, similarity on demand-side, similarity in capital market attributes, and similarity in legal ownership.

Yin (2003) lists six sources of evidence that can be served as the focus of data collection for case studies. These sources are documentation, archival records, interviews, direct observations, participant observation, and physical artifacts. Three of these sources are used in this study. Structured interviews of a majority of the managers at each SBU are used for the five research constructs. Archival records in the form of operating reports are used for all five variables. 
Gadjah Mada International Journal of Business, May-August 2005, Vol. 7, No. 2

Finally, direct observation is used for the independent variable (Deming's principle), primarily to corroborate and validate the findings from the structured interviews. The use of multiple informant helps with both the validity and reliability of the study. In addition, a database containing the various field notes, documents, and narratives collected over the course of the study was maintained to improve reliability (Smith and Reece 1999).

The structured interviews (the questionnaire development) was based on a compilation of previous assessing studies: the Deming's principle (Tamimi 1995 and 1998), world-class manufacturing practices (Flynn et al. 1999), operational excellence (Chevron Texaco 2003), company performance (Cook and Verma 2002). The questionnaire contained five broad types of questions. The first section asked the managers at the SBU level to respond to a set of fifty quality management practices, synthesized from Deming's philosophy of their establishments based on a five-point interval scale $(1=$ not at all true; $2=$ slightly true; $3=$ somewhat true; $4=$ mostly true; and $5=$ completely true). The second section contained a series of question measuring world-class company practices on five-point scale. The third section asked the managers to rate their relative reliability, efficiency, health, environmental, and safety dimensions of operational excellence; also on five-point scale. Sections four and five contained company performance dimensions (financial or mon- etary gain performance and non financial or value gain performance). Reliability and convergent validity assessment were performed after the survey has been accomplished by examining item-to-total correlation and employing confirmatory factor analysis, where several items were dropped for further analysis (see e.g. Tamimi 1995 and 1998; Flynn et al. 1999).

\section{Definitions and Operationalization of Variables}

The five constructs found in Appendix 1 are discussed in the following section. Deming's Principles (DP), was operationalized using a set of 50 quality management practices. These fifty quality management practices can be explained by Deming's 14 points (DP114). Deming's 14 points can be summarized as follows: (1) create constancy of purpose for improvement of product and service; (2) adopt new philosophy; (3) cease dependence on mass inspection; (4) end the practice of awarding business on price tag alone; (5) improve constantly and perpetually the system of production and service; (6) institute training; (7) institute leadership; (8) drive of fear to ask or suggest; (9) break down barriers between staff areas; (10) eliminate slogans, exhortations, and targets for the workforce; (11) eliminate numerical quotas; (12) remove barriers to pride artisanship; (13) institute a vigorous program of education and training; (14) take action to accomplish the transformation (Goetsch and Davis 2000). Specifically, exploratory factor analy- 
Ciptono-Exploring the Linkages between Deming's Principle, World-Class Company,...

sis is employed to determine whether Deming's 14 points (DP1-14) collectively has positive and significant effect on Deming's Principles. The measures were developed based on Tamimi's studies $(1995,1998)$.

World-Class Company (WCC), was operationalized using sixty seven Hayes and Wheelwright dimensions. Hayes and Wheelwright (1984) developed their concept of world-class manufacturing based on six principles (HWP 1-6). Specifically, confirmatory factor analysis is employed to determine whether Hayes and Wheelwright's 67 dimensions has positive and significant effect on the six principles of world-class manufacturing. The measure was developed by Flynn et.al. 1999. The term worldclass company was used because these firms were associated with outstanding performance in the global oil and gas industry.

Operational Excellence (OE), was operationalized using five dimensions of operational excellence. The measure was adapted from Chevron Texaco 2003. In order to succed, ChevronTexaco must achieve world- class performance and exceed the capability of the strongest competitor. To do so, the management of the Chevron Texaco company develops the seven dimensions of tracking for success: quality of work life, world-class in safety, efficiency, health, reliability, environmental stewardship, speed and agility, partner of choice, quality of life in the communities, earning group and superior long-term stockholder returns.

Company Performance, was conceptualized by Cook and Verma's study (2002) according to two dimensions. The first dimension is relating to financial or monetary gain or MGP (i.e., profit, market share enhancement, and cost reduction). The second dimension is relating to non financial or value gain or VGP (i.e., product/service quality enhancement, delivery performance, customer and employee satisfaction, and community development impacts). Based on Cook and Verma (2002), the study described the company performance into two constructs: value gain performance construct and monetary gain performance construct.

Key Research Questions

This study addresses fourteen key research questions that enable us to understand the relationships of Deming's principle, world-class company, operational excellence, monetary gain performance, and value gain performance.

1. Do Deming's 14 Points individually and collectively comprise reliable and valid instrument for measuring Deming's Principle (DP)?

2. Do Hayes and Wheelwright Practices (HWP) elements individually and collectively comprise reliable and valid instrument for measuring World-Class Company (WCC)?

3. Do Operational Excellence $(\mathrm{OE})$ elements individually and collectively comprise reliable and valid instrument formeasuring Operational Excellence $(\mathrm{OE})$ ? 
Gadjah Mada International Journal of Business, May-August 2005, Vol. 7, No. 2

4. Do Monetary Gain Performance (MGP)elements individually and collectively comprise reliable and valid instrument for measuring Monetary GainPerformance (MGP)?

5. Do Value Gain Performance(VGP) elements individually and collectively comprise reliable and valid instrument for measuring Value Gain Performance(VGP)?

6. Does Deming's Principles (DP) have a direct and significant effect on Monetary Gain Performance (MGP)?

7. Does Deming's Principles (DP) have a direct and significant effect on Value Gain Performance (VGP)?

8. Does Deming's Principles (DP) have a direct and significant effect on World-class Company (WCC)?

9. Does Deming'sPrinciples (DP) have a direct and significanteffectonOperational Excellence(OE)?

10. Does Deming's Principles (DP) have an indirect and significant effect on Monetary Gain Performance (MGP) through its direct effect on World-Class Company (WCC)?

11. Does Deming's Principles (DP) have an indirect and significant effect on Monetary Gain Performance (MGP) through its direct effect on Operational Excellence $(\mathrm{OE})$ ?

12. Does Deming's Principles (DP) have an indirect and significant effect on Value Gain Performance (VGP) through its direct effect on World-Class Company (WCC)?

13. Does Deming's Principles (DP) have an indirect and significant effect on Value Gain Performance (VGP) through its direct effect on Operational Excellence $(\mathrm{OE})$ ?

14. Does Value Gain Performance (VGP) have a direct and significant effect on Monetary Gain Performance (MGP) for the first scenario of structural analysis?

\section{Hypotheses Development}

The research framework (Appendix 1) which identifies a nine-stage path analytic model (structural model) delineating the factors involved in the relationships between five research constructs. On the basis of a review of the diffusion of distinctive literatures, the researcher posits fourteen quantitative-deductive research hypotheses to test the effect of Deming's Principle on Company Performance(Monetary Gain Performance and Value Gain Performance) through World-class Company and Operational Excellence and to investigate the interrelationships between
Deming's Principle, World-Class Company, Operational Excellence, and Company Performance.

The case study (explanatory) research hypotheses include two groups of hypotheses. The first group of hypothesis is concerned with the measurement analysis of the Deming's Principle (DP), World-Class Company (WCC), Operational Excellence (OE), Monetary Gain Performance (MGP), and Value Gain Performance (VGP) and their elements. The second group of hypothesis deals with the predictive power of these elements (the structural analysis). 
Ciptono-Exploring the Linkages between Deming's Principle, World-Class Company,...

The first group of hypotheses of measurement analysis consists of five hypotheses:

1. H1: Deming's 14 Points individually and collectively comprise reliable and valid instrument for measuring Deming's Principle (DP).

2. H2: Hayes and Wheelwright Practices (HWP) elements individually and collectively comprise reliable and valid instrument for measuring World-Class Company (WCC).

3. H3: Operational Excellence $(\mathrm{OE})$ elements individually and collectively comprise reliable and valid instrument for measuring Operational Excellence (OE).

4. H4: Monetary Gain Performance (MGP) elements individually and collectively comprise reliable and valid instrument for measuring Monetary Gain Performance (MGP).

5. H5: Value Gain Performance (VGP) elements individually and collectively comprise reliable and valid instrument for measuring Value Gain Performance (VGP).

The second group of hypotheses of structural analysis consists of nine hypotheses:

1. H6: Deming's Principles (DP) has a direct and significant effect on Monetary Gain Performance (MGP).

2. H7: Deming's Principles (DP) has a direct and significant effect on Value Gain Performance (VGP).

3. H8: Deming's Principles (DP) has a direct and significant effect on World-class Company (WCC).

4. H9: Deming's Principles (DP) has a direct and significant effect on Operational Excellence (OE).

5. H10: Deming's Principles (DP) has an indirect and significant effect on Monetary Gain Performance (MGP) through its direct effect on World-Class Company (WCC).

6. H11: Deming's Principles (DP) has an indirect and significant effect on Monetary Gain Performance (MGP) through its direct effect on Operational Excellence (OE).

7. H12: Deming's Principles (DP) has an indirect and significant effect on Value Gain Performance (VGP) through its direct effect on World-Class Company (WCC).

8. H13: Deming's Principles (DP) has an indirect and significant effect on Value Gain Performance (VGP) through its direct effect on Operational Excellence (OE).

9. H14: Value Gain Performance (VGP) has a direct and significant effect on Monetary Gain Performance (MGP) for the first scenario of structural analysis. 
Gadjah Mada International Journal of Business, May-August 2005, Vol. 7, No. 2

\section{Data Analyzes Methods}

The data (quantitative) generated in the preceding stages were analyzed using factor analysis (confirmatory factor analysis or CFA and exploratory factor analysis or EFA), structural equation modeling or SEM and path analysis. These statistical methods were selected because they were most appropriate for this study, given its objectives.

Factor Analysis is a data reduction technique used to reduce a large number of variables to a smaller set of underlying factors that summarize the essential information contained in the variables. Structural equation modeling (SEM) is a statistical methodology that take a confirmatory (i.e., hypothesis-testing) approach to the analysis of a structural theory bearing on some phenomenon. Typically, this theory represents causal processes that generate observations on multiple variables (Bentler 1988 in Byrne 2001). Path analysis is used to refer to the set of structural equations representing the postulated causal and non causal relationships among the variables under consideration (Land 1969).

The software programs AMOS (Analysis of Moment Structures or Analysis of Mean and Covariance Structures) version 4.01 (Arbuckle 1999), SPSS 11.0 (Coakes and Stead 2003) were used for the quantitative data analyses. As one of the SEM (Structural Equation Modeling) software program, AMOS facilitates the specification process by automatically incorporating the estimation of variances by default for all independent factors (Byrne 2001).

\section{Data Screening}

The first step in the factor analysis process is to explore the characteristics of the data. It is often useful to be able to conduct normality and multi-collinearity. Analysis on subsets of the data and to make conditional transformations of variable (Coakes and Steed 2003). These can be achieved using the normality and multicollinearity assumptions and practical considerations underlying the application of principle axis factoring (PAF) and principle components (PC).

According to Coakes and Stead (2003), the anti-image correlation matrix is used to assess the sampling adequacy each variable. The measures of sampling adequacy are displayed on the diagonal of the anti-image correlation matrix. Variables with a measure of sampling accuracy that falls below the acceptable level of 0.5 should be excluded from the analysis. Bartlett's test of sphericity and the Kaiser-MeyerOlkin (KMO) measure of sampling adequacy are both tests that can be used to determine the factorability of the matrix as a whole. If Bartlett's test of sphericity is large and significant, and if the Kaiser-Meyer-Olkin measure is greater than 0.6 , then factorability is assumed. An examination of the correlation matrix indicates that considerable number of correlations exceed 0.3 and thus the matrix is suitable for factoring. 
Ciptono-Exploring the Linkages between Deming's Principle, World-Class Company,...

Table 1. Normality and Multicollinearity Statistics Tests

\begin{tabular}{|c|c|c|c|c|c|c|}
\hline $\begin{array}{c}\text { Variable } \\
\text { (Construct) }\end{array}$ & $\begin{array}{l}\text { VIF) } \\
(<10)\end{array}$ & $\begin{array}{c}\text { Correlation } \\
\text { Matrix } \\
(>0.3)\end{array}$ & $\begin{array}{c}\text { Anti- } \\
\text { Image } \\
\text { Corelation } \\
\text { Matrix } \\
\text { Diagonal } \\
\text { Value) } \\
(>0.5)\end{array}$ & $\begin{array}{c}\text { KMO } \\
\text { Measure of } \\
\text { Sampling } \\
\text { Adequacy } \\
\text { (>0.6) }\end{array}$ & $\begin{array}{l}\text { Bartlett's } \\
\text { Sphericity } \\
\text { (Large and } \\
\text { Significant) }\end{array}$ & $\begin{array}{c}\text { Normally } \\
\text { Distributed }\end{array}$ \\
\hline DP & 3.347 & $0.736-0.822$ & $>0.882$ & 0.903 & $\begin{array}{c}5919.358 ; \text { df } 28 \\
\text { (significant, } \mathrm{p}<0.000 \text { ) }\end{array}$ & $\begin{array}{l}\text { Standard deviation } 0.61 \\
\text { mean } 3.53\end{array}$ \\
\hline WCC & 3.269 & $0.557-0.651$ & $>0.680$ & 0.931 & $\begin{array}{l}114895.300 ; \text { df } 8515 \\
\text { (significant, } \mathrm{p}<0.000 \text { ) }\end{array}$ & $\begin{array}{l}\text { Standard deviation } 0.44 \\
\text { Mean } 3.03\end{array}$ \\
\hline $\mathrm{OE}$ & 1.990 & $0.511-0.648$ & $>0.791$ & 0.830 & $\begin{array}{c}3105.893 ; \text { df } 10 \\
\text { (significant, } \mathrm{p}<0.000 \text { ) }\end{array}$ & $\begin{array}{l}\text { Standard deviation } 0.71 \\
\text { Mean } 3.47\end{array}$ \\
\hline MGP & 1.812 & $0.387-0.741$ & $>0.678$ & 0.712 & $\begin{array}{c}\text { 1023.040; df } 3 \\
\text { (significant, } \mathrm{p}<0.000 \text { ) }\end{array}$ & $\begin{array}{l}\text { Standard deviation } 0.55 \\
\text { Mean } 2.79\end{array}$ \\
\hline VGP & 2.108 & $0.494-0.741$ & $>0.832$ & 0.864 & $\begin{array}{c}3187.373 \text {; df } 15 \\
\text { (significant, } \mathrm{p}<0.000 \text { ) }\end{array}$ & $\begin{array}{l}\text { Standard deviation } 0.48 \\
\text { Mean } 2.75\end{array}$ \\
\hline
\end{tabular}

\section{Interpretation of Results}

A total of 1,332 individual usable questionnaires were returned thus qualified for analysis, representing an effective response rate of 50,19 percent. All 140 SBUs returned questionnaires from their high level manager, middle level manager, and low level manager. According to Black (1994), the typical response rate for a research survey is of the order of 15-20 percent.

One hundred and thirty one (131) questionnaire items of the relationship of Deming's Principle, World-Class Company, Operational Excellence, Monetary Gain Performance, and Value Gain Performance. After reversed scores were adjusted, items rep- resenting the constructs and dimensions were subjected to reliability and validity tests. Rigorous statistical analysis is required in order to meet professional standards of validity and reliability.

a. Reliability and Validity of Measures. Cronbach's alpha coefficients were computed to estimate the reliability of each scale (observed variable or indicator). The Cronbach's alpha of the measures are ranging from 0.8119 to 0.9147 , which, according to DeVellis (1991), are respectable to very good. Table 2 shows the reliability of the measures. Table 3 summarizes the number of items retained of the research constructs. 
Gadjah Mada International Journal of Business, May-August 2005, Vol. 7, No. 2

Table 2. Reliability Coefficients (Cronbach's Alpha) of the Constructs

\begin{tabular}{|c|c|c|c|}
\hline Construct & $\begin{array}{c}\text { Number of Items } \\
\text { in the Questionnaire }\end{array}$ & $\begin{array}{c}\text { Number of Items } \\
\text { Retained }\end{array}$ & $\begin{array}{c}\text { Cronbach's } \\
\text { Alpha }\end{array}$ \\
\hline DP & 14 Items & 8 Items & 0.9147 \\
\hline WCC & 6 Items & 4 Items & 0.8475 \\
\hline $\mathrm{OE}$ & 5 Items & 3 Items & 0.9106 \\
\hline MGP & 3 Items & 3 Items & 0.8119 \\
\hline VGP & 6 Items & 6 Items & 0.8702 \\
\hline
\end{tabular}

Table 3. Number of Items Retained of The Research Constructs

\begin{tabular}{|c|c|c|}
\hline Construct's Name & $\begin{array}{l}\text { Construct } \\
\text { Item Code }\end{array}$ & Sub Construct Item Code \\
\hline $\begin{array}{l}\text { Deming's } \\
\text { Principles (DP) }\end{array}$ & $\begin{array}{l}\text { DP1 } \\
\text { DP2 } \\
\text { DP3 } \\
\text { DP4 } \\
\text { DP5 } \\
\text { DP6 } \\
\text { DP7 } \\
\text { DP8 }\end{array}$ & $\begin{array}{l}\text { QMP 1, 2, 3, } 4 \\
\text { QMP 5, 6, } 7 \\
\text { QMP 8, 9, } 10 \\
\text { QMP 11, 12, } 13 \\
\text { QMP 15, 16, 17 } \\
\text { QMP 18, 19, 20, } 21 \\
\text { QMP 22, 23, 24, } 25 \\
\text { QMP 26, 27, 28, } 29\end{array}$ \\
\hline $\begin{array}{l}\text { World-class } \\
\text { Company (WCC) }\end{array}$ & $\begin{array}{l}\text { HWP1 } \\
\text { HWP2 } \\
\text { HWP3 } \\
\text { HWP4 }\end{array}$ & $\begin{array}{l}\text { Hayes-Wheelwright dimensions: } 51,54,55,56,57,58 \\
\text { Hayes-Wheelwright dimensions: } 59,60,62,63,64,65 \text {, } \\
66,67,68 \\
\text { Hayes-Wheelwright dimensions: } 72,73,74,75,76,78 \\
\text { Hayes-Wheelwright dimensions: } 80,82,83,84,85,88 \text {, } \\
89,90,91\end{array}$ \\
\hline $\begin{array}{l}\text { Operational } \\
\text { Excellence (OE) }\end{array}$ & $\begin{array}{l}\text { OE1 } \\
\text { OE2 } \\
\text { OE3 }\end{array}$ & OE (OE1, OE2, OE3) \\
\hline $\begin{array}{l}\text { Monetary Gain } \\
\text { Performance (MGP) }\end{array}$ & $\begin{array}{l}\text { MGP1 } \\
\text { MGP2 } \\
\text { MGP3 }\end{array}$ & MGP (MGP1, MGP2, MGP3) \\
\hline $\begin{array}{l}\text { Value Gain } \\
\text { Performance (VGP) }\end{array}$ & $\begin{array}{l}\text { VGP1 } \\
\text { VGP2 } \\
\text { VGP3 } \\
\text { VGP4 } \\
\text { VGP5 } \\
\text { VGP6 }\end{array}$ & VGP (VGP1, VGP2, VGP3, VGP4, VGP5, VGP6) \\
\hline
\end{tabular}


Ciptono-Exploring the Linkages between Deming's Principle, World-Class Company,...

Table 4. Construct Reliability

\begin{tabular}{|c|c|c|c|}
\hline Construct & $\varepsilon$ & $\lambda$ & $\alpha$ \\
\hline DP (Before deleted components 9-14) & 0.0600 & 0.8190 & 0.9910 \\
\hline DP (After deleted components 9-14) & 0.0270 & 0.8190 & 0.9620 \\
\hline WCC (Before deleted components 5 and 6 ) & 0.0217 & 0.7866 & 0.9661 \\
\hline WCC ( After deleted components 5 and 6 ) & 0.0379 & 0.8186 & 0.9465 \\
\hline $\mathrm{OE}$ & 0.1387 & 0.5999 & 0.7218 \\
\hline MGP & 0.0567 & 0.4976 & 0.8136 \\
\hline VGP & 0.0248 & 0.4508 & 0.8912 \\
\hline
\end{tabular}

After the scales had met the necessary levels of reliability, the scales were assessed for validity. Confirmatory factor analysis was to assess the validity of each scales, which consisted of the retained items or manifest indicators. All loadings (path coefficients or regression weights) from a latent construct to their corresponding manifest indicators were significant (critical ratio values $>1.96$ ). Thus provided evidence of convergent validity.

This study also assessed the discriminant validity of the latent constructs. Discriminant validity is the degree to which two conceptually similar constructs are distinct. According to Anderson and Gerbing (1988), when the confidence interval of \pm two standard errors around a correlation estimate between two factors (constructs) does not include the value 1 , that is evidence of discriminant validity for the two constructs. None of the confidence intervals in this study included one. b. Construct Reliability $(\alpha)$. The composite reliability of each latent construct $(\alpha)$ measures the internal consistency of the construct indicators, depicting degree to which they indicate the common latent (unobserved) construct. High reliability of measures provides the researcher with greater confidence that the individual indicators consistently measure the same measurements (see Table 5). The threshold value for acceptable reliability is 0.70 . (Hair et al. 1998).

\section{c. Fixing the Error Terms and the} Lambdas. Single indicators measured latent constructs of this study; however, in each case, the indicator was a multiple-item scale. It is unlikely that a single indicator perfectly measures a construct; therefore, this study estimated the measurement error terms. The measurement error terms were fixed at $(1-\alpha)$ $\sigma^{2}$ and the corresponding lambdas the loading from a latent construct to its corresponding indicator- were 
Gadjah Mada International Journal of Business, May-August 2005, Vol. 7, No. 2

fixed at $\alpha^{1 / 2} \sigma$ (Howell 1987). For the non-latent (observed) variables, the error terms were fixed at 0 and the corresponding lambdas were fixed at 1 .

The measure of this study consists of indicators five latent variables measured based on a 5 point scale. Therefore, before fixing the error terms and the lambdas for the samples, the study converted those latent variables into standard scores ( $\mathrm{Z}$ scores) by subtracting the mean and dividing by the standard deviation for each variable. Using standardized variables eliminates the effects due to scale differences (Hair et.al. 1998). Table 4 provides the reliability of the constructs, lambdas, and error terms.

d. EFA for Deming's Principle (DP) Construct. An exploratory principle components factor analysis was conducted to determine whether the Deming's 14 points load collectively an overall constructs that may be termed as Deming's Principles (DP) - hypothesis 1 was supported. All Deming's 14 points were extracted that accounted for 58.768 percent of the total variation in the observed variable and all of the 14 component matrix value above 0.5 . All of Deming's 14 points collec-

Table 5. The Result of Exploratory Factor Analysis: Deming's Principle

\begin{tabular}{|c|c|c|c|c|c|c|c|}
\hline \multirow[b]{2}{*}{ Component } & \multicolumn{3}{|c|}{ Initial Eigenvalues } & \multicolumn{3}{|c|}{$\begin{array}{c}\text { Extraction Sums } \\
\text { of Squared Loading }\end{array}$} & \multirow{2}{*}{$\begin{array}{c}\begin{array}{c}\text { Component } \\
\text { Matrix }\end{array} \\
\text { Component } 1\end{array}$} \\
\hline & Total & $\begin{array}{c}\% \text { of } \\
\text { Variance }\end{array}$ & $\begin{array}{c}\text { Comulative } \\
\%\end{array}$ & Total & $\begin{array}{c}\% \text { of } \\
\text { Variance }\end{array}$ & $\begin{array}{c}\text { Cumulativre } \\
\%\end{array}$ & \\
\hline$\xi 1$ & 8.227 & 58.768 & 58.768 & 8.227 & 58.768 & 58.768 & 0.747 \\
\hline$\xi 2$ & 0.896 & 6.402 & 65.169 & & & & 0.757 \\
\hline$\xi 3$ & 0.735 & 5.247 & 70.417 & & & & 0.779 \\
\hline$\xi 4$ & 0.622 & 4.443 & 74.860 & & & & 0.688 \\
\hline$\xi 5$ & 0.548 & 3.911 & 78.771 & & & & 0.749 \\
\hline$\xi 6$ & 0.485 & 3.463 & 82.234 & & & & 0.779 \\
\hline$\xi 7$ & 0.427 & 3.052 & 85.287 & & & & 0.808 \\
\hline$\xi 8$ & 0.399 & 2.853 & 88.140 & & & & 0.788 \\
\hline$\xi 9$ & 0.345 & 2.465 & 90.604 & & & & 0.749 \\
\hline$\xi 10$ & 0.307 & 2.191 & 92.795 & & & & 0.790 \\
\hline$\xi 11$ & 0.283 & 2.024 & 94.820 & & & & 0.786 \\
\hline$\xi 12$ & 0.261 & 1.864 & 96.684 & & & & 0.755 \\
\hline$\xi 13$ & 0.240 & 1.717 & 98.402 & & & & 0.780 \\
\hline$\xi 14$ & 0.224 & 1.598 & 100.000 & & & & 0.773 \\
\hline
\end{tabular}

Extraction Method: Principal Component Analysis

1. Component Extracted: only one component was extracted. The solution cannot be rotated Components 9-14 should be deleted, because the total initial eigenvalues are $<0.4$ (Nunnally 1967) 
Ciptono-Exploring the Linkages between Deming's Principle, World-Class Company,...

tively have positive impact on "Deming's Principles. Table 5 shows the result of Exploratory Factor Analysis: Deming's principle. Components with a measure of total initial Eigen values that falls below the acceptable level of 0.4 should be excluded from the analysis (i.e., components 9 -14) (Nunnally 1967) -there are 8 components of Deming's principle should be considered in this study (components 18).

\section{EFA for World-Class Company (WCC) Construct}

An exploratory principle components factor analysis was conducted to determine whether the Hayes and Wheelwright's six dimensions (HWP
1-6) load collectively an overall constructs that may be termed as WorldClass Company (WCC). All Hayes and Wheelwright's six dimensions (HWP 1-6) were extracted that accounted for 60.436 percent of the total variation in the observed variable and all of the 6 component matrixes valued above 0.5 . All Hayes and Wheelwright's six dimensions (HWP 1-6) collectively have positive impact on World-Class Company (WCC) -hypothesis 2 was supported. Table 6 shows the result of Exploratory Factor Analysis: WorldClass Company or WCC. Components with a measure of total initial Eigen values that falls below the acceptable level of 0.4 should be excluded from the analysis (i.e., components 5 and 6) (Nunnally 1967).

Table 6. The Result of Exploratory Factor Analysis: World-class Company (WCC) Total Variance Explained

\begin{tabular}{|c|c|c|c|c|c|c|c|}
\hline \multirow[b]{2}{*}{ Component } & \multicolumn{3}{|c|}{ Initial Eigenvalues } & \multicolumn{3}{|c|}{$\begin{array}{c}\text { Extraction Sums } \\
\text { of Squared Loading }\end{array}$} & \multirow{2}{*}{$\begin{array}{c}\begin{array}{c}\text { Component } \\
\text { Matrix }\end{array} \\
\text { Component } 1\end{array}$} \\
\hline & Total & $\begin{array}{c}\text { \% of } \\
\text { Variance }\end{array}$ & $\begin{array}{c}\text { Comulative } \\
\%\end{array}$ & Total & $\begin{array}{c}\% \text { of } \\
\text { Variance }\end{array}$ & $\begin{array}{c}\text { Cumulativre } \\
\%\end{array}$ & \\
\hline 1 & 3.626 & 60.436 & 60.436 & 3.626 & 60.436 & 60.436 & 0.792 \\
\hline 2 & 0.710 & 11.835 & 72.272 & & & & 0.859 \\
\hline 3 & 0.558 & 9.298 & 81.570 & & & & 0.701 \\
\hline 4 & 0.494 & 8.226 & 89.796 & & & & 0.800 \\
\hline 5 & 0.317 & 5.279 & 95.075 & & & & 0.822 \\
\hline 6 & 0.295 & 4.925 & 100.000 & & & & 0.674 \\
\hline
\end{tabular}

Extraction Method: Principal Component Analysis

1. Component Extracted: only one component was extracted. The solution cannot be rotated Components 5 and 6 should be deleted, because the total initial Eigen values are $<0.4$ (Nunnally 1967) 
Gadjah Mada International Journal of Business, May-August 2005, Vol. 7, No. 2

\section{CFA for Operational Excellence (OE) Construct}

The result of Confirmatory Factor Analysis (CFA) for Operational Excellence (OE) construct shows that only three factors have significant and positive impact on Operational Excellence $(\mathrm{OE})-\mathrm{H} 3$ was supported by the three factors of OE. The Cronbach's alpha for the overall scale as equal to 0.893. An examination of the item compressing the Operational Excellence construct indicates that item four and five have the highest corrected items-total correlations. If these items were removed from the scale, the Alpha if Item Deleted column shows as that overall reliability would increase slightly. When the researcher removes these items and recalculated the reliability coefficient, Cronbach' alpha is a raised slightly to 0.911 . Therefore, deletion of these items may be considered appropriate.

\section{CFA for Monetary Gain Performance (MGP) Construct}

The result of Confirmatory Factor Analysis (CFA) for Monetary Gain Performance (MGP) construct shows that the three factors have significant and positive impact on Monetary Gain Performance (MGP)-H4 was supported. The result shows the reliability of three dimensions of the Monetary Gain Performance (MGP) construct computed by Cronbach's alpha, varied from 0.718 to 0.770 , suggesting an acceptable internal consistency, especially given the number of item
(Nunnally 1978). The Cronbach's alpha for the overall scale as equal to 0.812 .

\section{CFA for Value Gain \\ Performance (VGP) Construct}

The result of Confirmatory Factor Analysis (CFA) for Value Gain Performance (VGP) construct shows that the six factors have significant and positive impact on Value Gain Performance (VGP) - H5 was supported. Constructs computed by Cronbach's alpha, varied from 0.831 to 0.865 , suggesting an acceptable internal consistency, especially given the number of item (Nunnally 1978). The Cronbach's alpha for the overall scale as equal to 0.870 .

\section{Assessment of Structural Model Fit}

Table 7 presented the initial (original) structural model and the goodness-of -fit statistics results. The estimation of parameters in the model was determined using maximum likelihood (ML) estimation (Bollen 1989; Bentler 1990, Joreskog and Sorbom 1989). Eight criteria for accessing for overall fit were used: $X^{2}, X^{2} / d f$, GFI, AGFI, CFI, RMR, RMSEA, and p-valuebased on the acceptable or desirable parameter level (Hair et al. 1998). A summary of selected fit indices for the EQS analysis (initial model) is provided in Table 7. While this model fits perfectly $(\mathrm{GFI}=1, \mathrm{CFI}=1$, and $\mathrm{RMR}=$ $0)$, but $X^{2} / d f$, AGFI, and $p$-value are not available. Interpretation of the con- 
Ciptono-Exploring the Linkages between Deming's Principle, World-Class Company,...

Table 7. SEM Results (The Initial/Original Model)

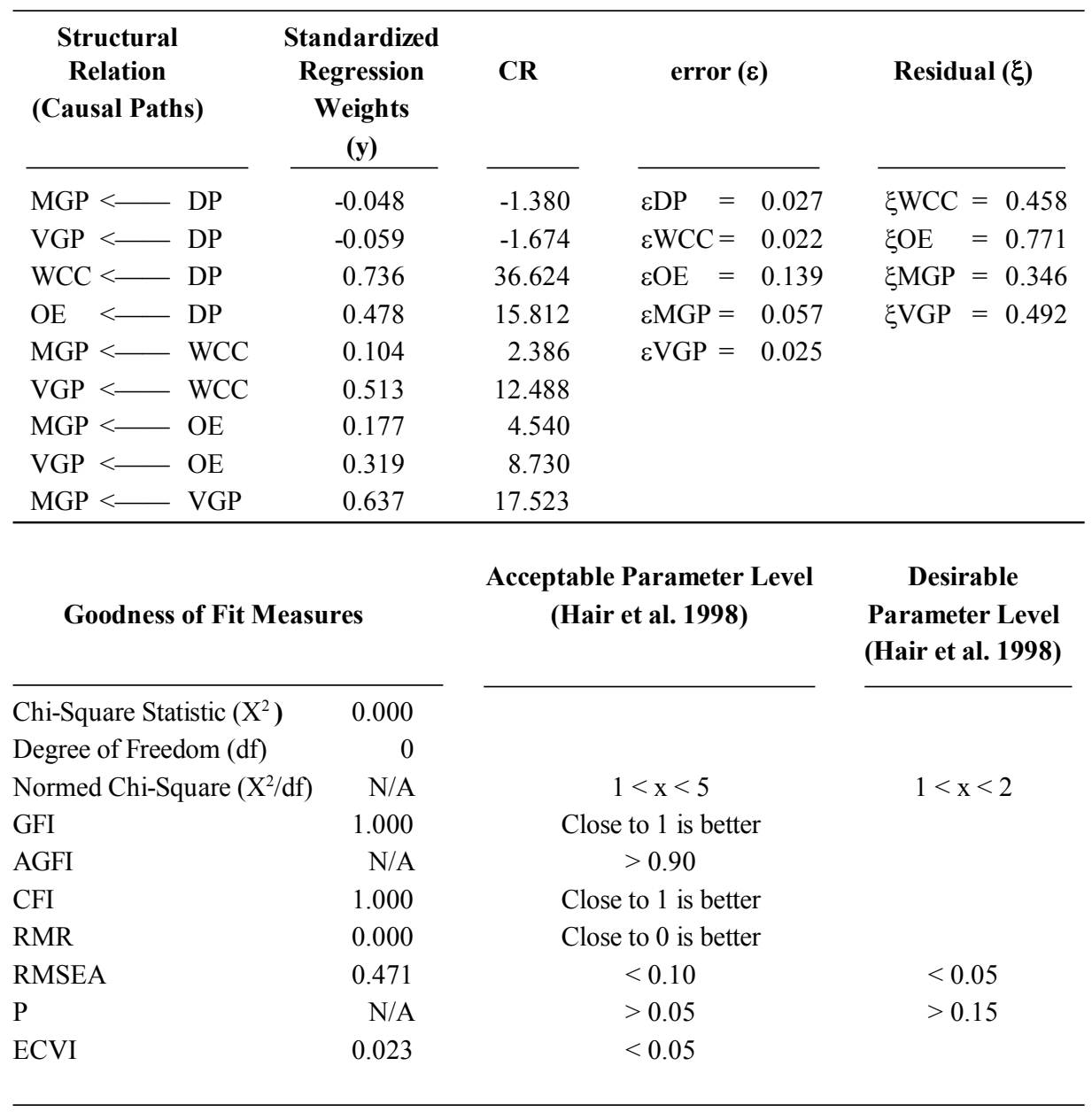

fident interval indicates that the author can be 90 percent confident that the true RMSEA value (0.471) in the population will greater than 0.10 indicate poor fit.

The hypothesized (initial) model depicted in Appendix 2. The initial structural model supported hypotheses H8-H14, although the model fit showed the marginal satisfactory goodnessof-fit indices. Unfortunately, hypotheses $\mathrm{H} 6$ and $\mathrm{H} 7$ were not confirmed since the paths from Deming's Principle (DP) to Monetary Gain Performance (MGP) and from Deming's Principle (DP) to Value Gain Performance (VGP) were not significant and negative effect - the critical ratio values (CR) were negative (these indicate statistically insignificant). Therefore, the path DP to VGP was eliminated and the model was revised.

Table 8 shows the direct effect and indirect effects of the one exog- 
Gadjah Mada International Journal of Business, May-August 2005, Vol. 7, No. 2

Table 8. The Direct and Indirect Effects of the One Exogenous Variable and the Intervening Variables on Company Performance

\begin{tabular}{|c|c|c|c|c|c|}
\hline \multirow[t]{2}{*}{$\begin{array}{c}\text { Dependent } \\
\text { Variable }\end{array}$} & \multirow[t]{2}{*}{$\begin{array}{l}\text { Predetermined } \\
\text { Variable }\end{array}$} & \multirow[t]{2}{*}{$\begin{array}{c}\text { Total } \\
\text { Effect }\end{array}$} & \multicolumn{2}{|c|}{$\begin{array}{c}\text { Indirect Effects } \\
\text { Via }\end{array}$} & \multirow[t]{2}{*}{$\begin{array}{l}\text { Direct } \\
\text { Effect }\end{array}$} \\
\hline & & & WCC & $\mathbf{O E}$ & \\
\hline WCC & DP & 0.736 & - & - & 0.736 \\
\hline $\mathrm{OE}$ & DP & 0.478 & - & - & 0.478 \\
\hline MGP & DP & 0.414 & 0.379 & 0.083 & -0.048 \\
\hline MGP & VGP & 0.637 & - & - & 0.637 \\
\hline VGP & DP & 0.471 & 0.337 & 0.193 & -0.059 \\
\hline
\end{tabular}

t-value significance at the $p=0.000$

enous variable (DP) and the two intervening variables (WCC and $\mathrm{OE}$ ) on company performance (MGP and VGP). This result provided by the path analysis do allow for some meaningful interpretation and potential contribution. For example the direct effects of DP on MGP and DP on VGP are negative. However, DP has positive indirect and significant effects on MGP and VGP through its positive direct effects on WCC and OE in light of the positive total effects.

Table 9 shows the revised structural model 1. After eliminating the path from DP to VGP, the GFI, AGFI, and CFI were iteratively used to determine whether the structural model fitted the data well. Taken together, these results suggest the hypothesized model is well-fitting and represents a reasonable approximation to the population $\left(\mathrm{X}^{2} / \mathrm{df}<3\right.$; GFI, AGFI, CFI $>0.90$; RMR and RMSEA $<0.05$; and $p$-value $>0.05$ ). Turning to Table 9 , again we see that the path from DP to MGP is not significant in this reduced model $\mathrm{CR}$ value was negative. This path should be eliminated and further modification was needed to improve model fit to acceptable levels.

The fully revised structural model is presented in Table 10. All paths in the fully revised structural model are significant, so no further model reductions were attempted. The final model surpasses the hypothesized model on all fit criteria, which confirms that the modifications were meaningful. The final model is tenable from a content and theoretical standpoint. Although the final model (without the direct paths from DP to MGP and DP to VGP) appears to fit better, the revised model 1 also has adequate fit. The path analyses indicate that the DP affects MGP and VGP only through its direct effects on World-Class Company (WCC) and Operational Excellence (OE).

Most of the overall model fit indices (the goodness-of-fit-index or GFI= 
Ciptono-Exploring the Linkages between Deming's Principle, World-Class Company,...

Table 9. SEM Results (Revised Model 1)

\begin{tabular}{|c|c|c|c|c|c|}
\hline \multicolumn{2}{|c|}{$\begin{array}{c}\text { Structural } \\
\text { Relation } \\
\text { (Causal Paths) }\end{array}$} & $\begin{array}{l}\text { tandardized } \\
\text { Regression } \\
\text { Weights } \\
\text { (y) }\end{array}$ & CR & $\operatorname{error}(\varepsilon)$ & Residual ( $(\xi)$ \\
\hline MGP $<-$ & DP & -0.052 & -1.532 & $\varepsilon \mathrm{DP}=0.027$ & $\xi \mathrm{WCC}=0.459$ \\
\hline VGP $<-$ & DP (Deleted) & - & - & $\varepsilon \mathrm{WCC}=0.022$ & $\xi \mathrm{OE}=0.776$ \\
\hline $\mathrm{WCC}<-$ & DP & 0.735 & 36.564 & $\varepsilon \mathrm{OE}=0.139$ & $\xi \mathrm{MGP}=0.346$ \\
\hline $\mathrm{OE}<-$ & DP & 0.473 & 15.693 & $\varepsilon \mathrm{MGP}=0.057$ & $\xi \mathrm{VGP}=0.495$ \\
\hline MGP $<-$ & WCC & 0.108 & 2.500 & $\varepsilon \mathrm{VGP}=0.025$ & \\
\hline VGP $<-$ & WCC & 0.470 & 14.598 & & \\
\hline MGP $<-$ & $\mathrm{OE}$ & 0.177 & 4.549 & & \\
\hline VGP $<-$ & $\mathrm{OE}$ & 0.317 & 8.664 & & \\
\hline MGP $<-$ & VGP & 0.638 & 17.635 & & \\
\hline \multicolumn{3}{|c|}{ Goodness of Fit Measures } & \multicolumn{2}{|c|}{$\begin{array}{l}\text { Acceptable Parameter Level } \\
\text { (Hair et al. 1998) }\end{array}$} & $\begin{array}{c}\text { Desirable } \\
\text { Parameter Level } \\
\text { (Hair et al. 1998) }\end{array}$ \\
\hline Chi-Square Sta & tistic $\left(\mathrm{X}^{2}\right)$ & 2.802 & & & \\
\hline Degree of Free & $\operatorname{lom}(\mathrm{df})$ & 1.000 & & & \\
\hline Normed Chi-Sc & uare $\left(\mathrm{X}^{2} / \mathrm{df}\right)$ & 2.802 & & $1<x<5$ & $1<x<2$ \\
\hline GFI & & 0.999 & & to 1 is better & \\
\hline AGFI & & 0.987 & & $>0.90$ & \\
\hline $\mathrm{CFI}$ & & 0.999 & & to 1 is better & \\
\hline RMR & & 0.003 & & to 0 is better & \\
\hline RMSEA & & 0.037 & & $<0.10$ & $<0.05$ \\
\hline$P$ & & 0.094 & & $>0.05$ & $>0.15$ \\
\hline ECVI & & 0.023 & & $<0.05$ & \\
\hline
\end{tabular}

0.998; the goodness-of-fit-index adjusted for degrees of freedom or AGFI $=0.988$; the root mean square error of approximation or RMSEA= 0.034 ; the root mean square residual or $\mathrm{RMR}=0.004$; the comparative fit index or $\mathrm{CFI}=0.999$ ); and $\mathrm{p}$-value $=0.077$ thus suggesting that the contending model represented a superior fit to the data. Because of the goodness-of-fit statistics resulting from this analysis is a well-fitting model, this model is ac- cepted. This attempt has improved the Normed Chi-square from 2.802 to 2.569 as well as the RMSEA from 0.037 to 0.034 .

It means that the Indonesia's oil and gas companies should try to interpret of such guidelines to help managers at the SBU level to measure or implement Deming's principle. Thus, reducing Deming's 14 points into a smaller set of meaningful factors (i.e., eight factors) should aid the Indonesia's 
oil and gas managers in their "Demingization" efforts. It should be pointed out, however, that by reducing Deming's 14 points into a smaller set of quality principles (eight factors), this study is not diminishing the importance of other factors. Rather, this study is testing whether the 14 points may be collapsed into a smaller set of quality practices for easier implementation (Tamimi 1995).

This study also provides important insights into the consistent and smallest all ECVI values (Expected Cross-Validation Index) from the initial model, revised model 1, and final model $(\mathrm{ECVI}=0.023)$. According to Byrne (2001) the structural model having the smallest ECVI values exhibits the greatest potential for replication. In assessing thehypothesized for the structural model we compare its ECVI value of 0.023 with that of both the saturated model $(E C V I=0.023)$ and the independence model $(\mathrm{ECVI}=2.234)$. Given the lower ECVI value for the hypothesized model, compared with both the independence and saturated models, we conclude that it represents the best fit to the data.

Contrary to the proposed model, the Deming's Principle has no direct effects on monetary gain performance and value gain performance. The hypothesized relationship between Deming's Principle and monetary gain performance and value gain performance are not supported. It is important to note that the quality management practices (Deming's Principle) does not have its own set of measured indicators. Rather, it is linked indirectly to those measuring the worldclass company and operational excellence factors. However, the results suggest that the effects of Deming's Principle on World-Class Company and Value Gain Performance to Monetary Gain Performance have relatively greater positive effects.

In finalizing this revision on structural model assessment, Table 10 summarizes the results of testing each hypothesis and the associated causal path (Appendix 3). Appendix 3 is the best predictors of company performance (MGP and VGP) based on the goodness of fit measures $\left(\mathrm{X}^{2} / \mathrm{df}=2.569\right.$; $\mathrm{GFI}=0.998, \mathrm{AGFI}=0.988, \mathrm{CFI}=$ $0.999, \mathrm{RMR}=0.004, \mathrm{RMSEA}=0.034$ and $p$-value $=0.077$ ), even though the CR value of the path from WCC to MGP d" 1.96 (CR value= 1.943). Therefore, the deletion of this path may not be considered appropriate. The probability level (p-value) cannot be improved (the p-value would be decrease tremendously from 0.077 to 0.031 ), because all of good-of-fit statistic represent a well-fitting and a reasonable approximation for the population. In summary, seven of nine causal paths specified in the hypothesized model were found to be positive and statistically significant with small error $(\varepsilon)$ of five constructs (close to zero) and small residual $(\xi)$ of mediating and dependent variables $(<2.58)$.

These results are remarkable, but it does lend some credence to the data collection and measurement methods. With two modifications, the findings 
Ciptono-Exploring the Linkages between Deming's Principle, World-Class Company,...

Table 10. SEM Results (Revised Model 2, The Final/Contending Model)

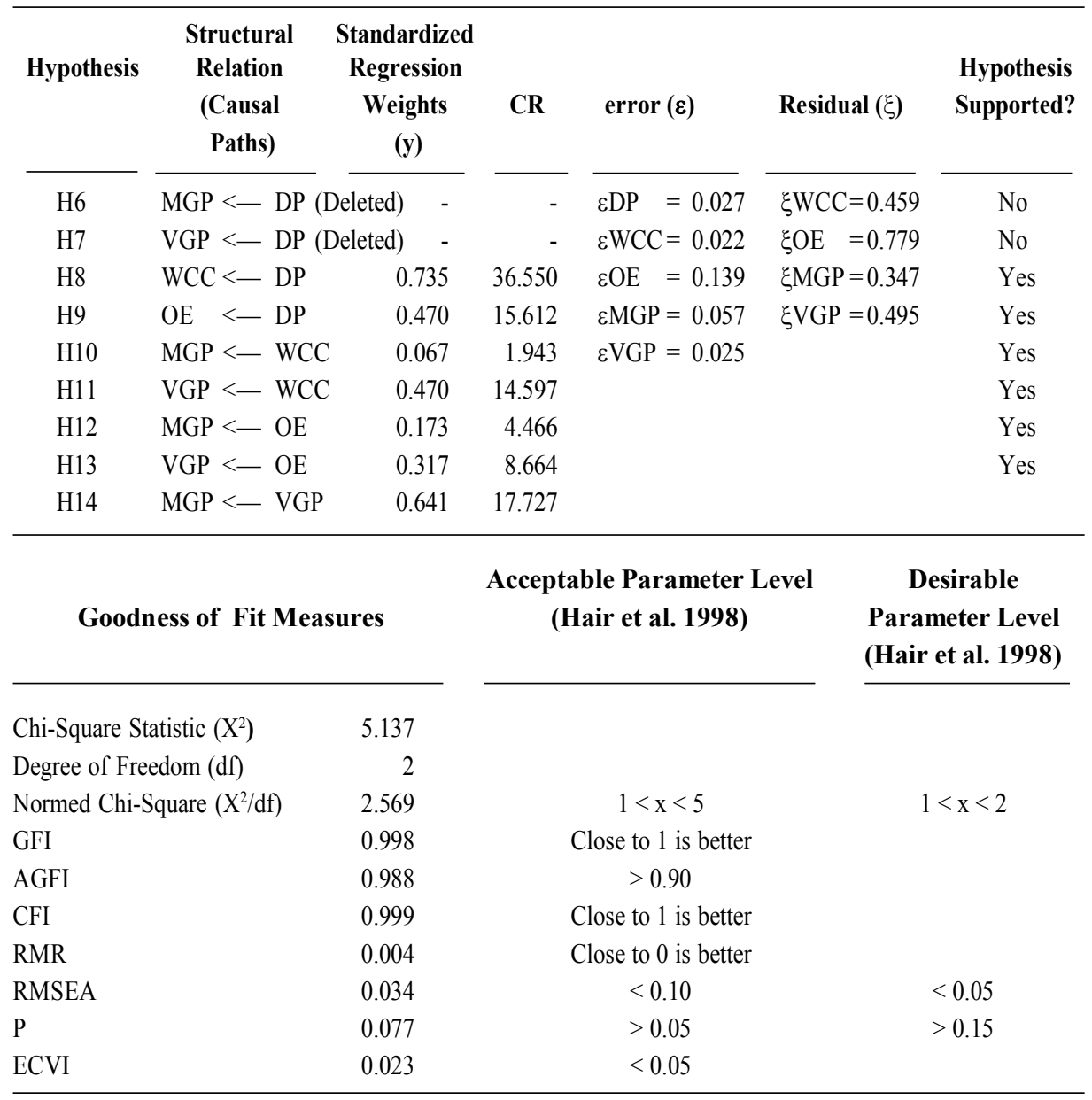

of the research support some degree of confidence to the study that used Deming's principle as surrogate measure for company performance (monetary gain performance and value gain performance) through world-class company and operational excellence. The contending model shown in Appendix 3 should be compared to the initial model in Appendix 2 and suggested that the contending model be accepted over the initial model, as the contending (final) model was more parsimonious. Identifying a final model without condition codes or signs of misspecification allowed the author to test hypotheses using the theoretical model (Johnson and Greening 1999).

Table 10 and Appendix 3 present results of the hypothesis tests. Overall, seven of nine hypotheses (H8-H14) were statistically significant in the predicted direction at a significance level of less than 0.05 or better. These are 
Gadjah Mada International Journal of Business, May-August 2005, Vol. 7, No. 2

Table 11. A Complete Model Fit: Initial Vs. Final Model

\begin{tabular}{|c|c|c|c|c|c|}
\hline \multirow[b]{2}{*}{$\begin{array}{c}\text { Goodness-of- Fit } \\
\text { Statistics Test }\end{array}$} & \multicolumn{2}{|c|}{ Model Fit for } & \multicolumn{3}{|c|}{ Acceptable Parameter Level for } \\
\hline & $\begin{array}{l}\text { Initial } \\
\text { Model }\end{array}$ & $\begin{array}{c}\text { Final } \\
\text { Causal } \\
\text { Model }\end{array}$ & $\begin{array}{c}\text { The Criteria of } \\
\text { Hair et al. } \\
1998\end{array}$ & $\begin{array}{l}\text { Initial } \\
\text { Model }\end{array}$ & $\begin{array}{c}\text { Final Causal } \\
\text { Model }\end{array}$ \\
\hline Chi-Square Statistic $\left(\mathrm{X}^{2}\right)$ & 0.000 & 5.137 & & & \\
\hline Degree of Freedom (df) & 0 & 2 & & & \\
\hline Normed Chi-Square (X²/df) & N/A & 2.569 & $1<x<5$ & No & Yes \\
\hline GFI & 1.000 & 0.998 & Close to 1 is better & Yes & Yes \\
\hline AGFI & N/A & 0.988 & $>0.90$ & No & Yes \\
\hline CFI & 1.000 & 0.999 & Close to 1 is better & Yes & Yes \\
\hline RMR & 0.000 & 0.004 & Close to 0 is better & Yes & Yes \\
\hline RMSEA & 0.471 & 0.034 & $<0.05$ & No & Yes \\
\hline $\mathrm{P}$ & N/A & 0.077 & $>0.05$ & No & Yes \\
\hline ECVI & 0.023 & 0.023 & $<0.05$ & Yes & Yes \\
\hline
\end{tabular}

within Deming's principle (eight components): (1) create constancy of purpose for improvement of product and service; (2) adopt new philosophy; (3) cease dependence on mass inspection; (4) end the practice of awarding business on price tag alone; (5) improve constantly and perpetually the system of production and service; (6) institute training; (7) institute leadership; and (8) drive of fear to ask or suggest) for company performance (monetary gain performance and value gain performance) were statistically significant through world-class company and operational excellence.

Table 11 shows a complete model fit and the acceptable parameter level of the research constructs which indicate the overall parameter of final or contending model are good fit between the hypothesized model and the observed data. The author compares the model fit for original and final, the results of the final model suggest that the hypothesized models are well-fitting and represent reasonable approximation to the population. The examinations to find these goodness-of-fit statistics of the final model with respect to the acceptable parameter level have encouraged the author to seek some modifications of the hypothesized models in the efforts to attain adequate fit to the data.

\section{Conclusions and Contributions}

Given that reliable and valid measures were needed for the research constructs, which are in turn important 
Ciptono-Exploring the Linkages between Deming's Principle, World-Class Company,...

for theory building, this study has developed and validated an appropriate measurement instrument for the causal relationships between Deming's principle, world-class company, operational excellence, and company performance (monetary gain performance and value gain performance). The ability of structural equation modeling (SEM) techniques to assess relationships comprehensively has provided a transition from exploratory to confirmatory analysis (Bollen 1989 in Samson and Terziovski 1999). The strong statistically significant for the causal relationships between Deming's principle, world-class company, operational excellence, and company performance (monetary gain performance and value gain performance) suggest that the findings are quite reliable.

By developing these causal relationships, the managers will be able to make rational judgments about how the journey of TQM (Deming's principles) should be implemented. The journey into TQM will be accomplished by implementing World-Class Company and Operational Excellence to raise the company performance. Being so, it will be helpful to examine the perspectives of people at various levels, and at various milestones along the way. This is presented not so much as a warning, but more to raise the sensitivity level of the manager of a total quality effort (Goetsch and Davis 2000).

The study is a timely research in Indonesia, so that it is important to explore and to show the relationship of world-class company and operational excellence as mediating variables between the independent variable of Deming's principle and the dependent variables of company performances (monetary gain performance and value gain performance) in an oil and gas industry setting (a single industry or case study research). The importance and the benefit of the research findings are to support the Indonesia's oil and gas companies to fulfill their vision to be recognized as World-Class Company committed to operational excellence based on the oil and gas policy reform.

The particular design of the research and the findings suggest that the structural model of the study has a great potential for replication to manufacturing as well as service operations. To do this, future research will need to recognize how service businesses are similar and different from manufacturing businesses in term of the causal relationship between Deming's principle, world-class company, operational excellence, and company performance. This translation of manufacturing (oil and gas industry) TQMbased systems to service organizations cannot be presumed and would have to be carefully thought out (Curkovic et al. 2000)

This study also provides several contributions to the field of TQM. First, the most contribution of the present investigation is the analysis of a large multiple informant of firms from the same industry (at the SBU level). The 
Gadjah Mada International Journal of Business, May-August 2005, Vol. 7, No. 2

advantage of concentrating on a single industry is that the model fit of structural equation modeling can be more specific because unique characteristic of the oil and gas industry can be included.

Second, this study demonstrates that Deming's Principle has significant positive and indirect effects on company performance through world-class company and operational excellence. This result may lend support to Deming's notion that improvements focus on world-class company and operational excellence, though often hard to quantify, are ultimately beneficial to the long-term health of the organization (Deming 1986).

Third, this study has utilized case study research method (field-based research) to examine concepts that seem reasonable, yet lack empirical verification. The particular design of the research and the findings suggest that much of the conceptual work in quality management practices may be applicable to manufacturing as well as service operation.

Finally, the implication of these findings for managers involved in an integrated oil and gas chain is highly significant. As a result of its amendment of law of the Republic of Indonesia concerning oil and natural gas, the Indonesia's oil and gas industry has a program under way to improve refinery level management, operations, and maintenance. The name of this program is Indonesia oil and gas refineries aiming for world-class operations. In addition the strong statistically sig- nificant results these relationships (Deming's Principle and World-Class Company, Value Gain Performance and Monetary Gain Performance) suggest that the findings are quite reliable. These findings provide evidence and support for other programs to build upon in trying to ascertain emerging patterns within the oil and gas field.

\section{Limitation of the Study}

The findings and conclusions of this study should be interpreted while keeping in mind the following limitations. It is important to note that the first potential limitation of this study stems from the use of a cross sectional analysis. Cross sectional analysis only give us portrayed at a particular point of time. The researcher can not examine the dynamic nature of trade-off which is changing over time (Silveira and Slack 2001). In addition the researcher encourages to think about whether the model of the study effects vary over time, either because other time the constructs are theoretically important or because the theoretical effect is unstable for some reason. Next research should be conducted longitudinally to observe the progress of improvement efforts (i.e., by developing Antecedents, Behavioral, Consequences analysis; or by using triangulation method).

A second limitation relates to the generalizability of the sample of single industry (the Indonesia's oil and gas industry; five digit of SIC Codes) to the larger population of wide variety 
Ciptono-Exploring the Linkages between Deming's Principle, World-Class Company,...

industries (two digit of SIC Codes) employing the successful quality management implementation for Worldclass Performance in Operations. To address this problem, next research should not emphasize on a single industry only, but the companies come from a wide ranges of industries (e.g. the classification of responding companies based on the two or three digit of SIC Codes) using a longitudinal study.

Third, one must be cautious in interpreting the findings of this study due to the companies restructuring policy into Strategic Business Units (SBUs) was relatively new. The potential problem with respect to the new policy implementation is a probability that SBUs lack of strategic consensus between policy maker (top level manager), middle level manager, and low level manager in the upstream, and downstream of oil and gas chains. As a result, the research findings are intended to represent the types of issues faced by strategic business units (SBUs) inexperienced in the implementation of Deming's Principle but nonetheless changed with the necessity of attaining successful TQM practices (Deming's principles) in order to develop worldclass company and operational excellence while also rising company performance.

\section{References}

Ahire, S.L., R. Landeros, and D. Y. Golhar. 1995. Total quality management: A literature review and an agenda for future research. Journal of Production and Operations Management 4 (3): 277- 306.

Achjari, D., and M. A. Quaddus. 2004. Electronic commerce success model: A search for multiplecriteria. Gadjah Mada International Journal of Business 6(1)(January): $1-27$.

Anderson, J. C., and D. W. Gerbing. 1988. Structural equation modeling in practice: A review and recommended two-step approach. Psychological Bulletin 103 (3): 411423.

Anderson, J. C., M. Rungtusanatham, and R. G. Schroeder. 1998. A theory of quality management underlying the Deming management method. Academy of Management Review 19 (3): 472-509.

Antony, J., K. Leung, G. Knowles, and S. Gosh. 2002. Critical success factors of TQM implementation in Hong Kong industries. International Journal of Quality and Reliability Management 19 (5): 551-566.

Arbukle, J. L., and W. Wothke. 1999. Amos 4.0. User's Guide. Chicago: Smallwaters.

Becker, S. W. 1993. TQM does work: Ten reasons why misguided efforts fail. Management Review 82 (5): 30-34.

Armstrong, J. S. 1979. Advocacy and objectivity in Science. Management Science Journal 25 (5) (May): 423-428. 
Gadjah Mada International Journal of Business, May-August 2005, Vol. 7, No. 2

Bentler, P. M. 1990. Comparative fit indexes in structural models. Psychological Bulletin 107 (2): 238-246.

Black, S. A. and L. J. Porter. 1996. Identification of the critical factors of TQM. Decision Sciences 27 (1): 1-21.

Bollen, K. A. 1989. Structural Equations with Latent Variables. New York: Wiley.

Bollen, K. A. 1989. A new incremental fit index for general structural models. Sociological Methods and Research 17: 303-316.

Brislin, R. W. 1986. The wording and translation of research instruments. In W. J. Looner and J. W. Berry (Eds.) Field Methods in Cross-Cultural Research. Beverly Hills, CA: Sage

Bryman, A., and E. Bell. 2003. Business Research Methods. New York: Oxford University Press, Inc.

Byrne, B. M.2001. Structural Equation Modeling with AMOS. New Jersey, Lawrence Erlbaum Associates, Inc., Publishers.

Chevron Texaco. 2003. Operational Excellence: Framework and Process Development Guidance (January). Jakarta.

Coakes, S. J., and L. H. Steed. 2003. SPPS: Analysis Without Anguish (Version 11.0 for Windows). Australia: John Wiley and Son, Ltd.

Cook, L. S., and R. Verma, R. 2002. Exploring the linkages between quality systems, service quality, and performance excellence: Service providers' perspectives. Quality management Journal 9 (2). http://www.asq.org/pub/qmj/past/vol9/issue2/ index.html.

Crosby, P. B. 1989. Quality is Free. New York: McGraw-Hill.

Curkovic, S., S. Melnyk, R. Calantone, and R. Handfield. 2000. Validating the Malcolm Baldrige National Quality Award framework through structural equation modelling. International Journal of Production Research 38 (4): 765-791.

Deming, W. E. 1986. Out of the Crisis. Cambridge, MA: MIT Press.

Embassy of the United States of America. 2004. Petroleum Report Indonesia 2002-2003 (March). Jakarta: USA Embassy.

Eskildson, L. 1994. Improving the odds of TQM's success. Quality Progress 27 (4): 61 63.

Flynn, B. B., R. G. Schroeder, and E. J. Flynn. 1999. World-class manufacturing: An investigation of Hayes and Wheelwright's foundation. Journal of Operation Management 17: 249-269.

Foster, G. 1998. Financial Statement Analysis (2 ${ }^{\text {nd }}$ ed.). New York: Prentice-Hall International, Inc.

Gefen, D., D. W. Straub, and M. C. Boudreau. 2000. Structural equation modeling and regression: Guidelines for research practice. Communication of the Association for Information Systems 4 (7): 1-77.

Goetsch, D. L., and S. B. Davis. 2000. Quality Management: Introduction to Total Quality Management for Production, Processing, and Services $\left(3^{\text {rd }}\right)$. Upper Saddle River, New Jersey: Prentice Hall. 
Ciptono-Exploring the Linkages between Deming's Principle, World-Class Company,...

Hackman, J. R., and R. Wageman. 1995. Total quality management: Empirical, conceptual, and practical issues. Administrative Science Quarterly 40 (1): 309-342.

Hair, J. F, Jr., R. E. Anderson, R. L. Tatham, and. W. C. Black. 1998. Multivariate Data Analysis. ( $5^{\text {th }}$ ed.). Englewood Cliffs, New Jersey: A Simon and Schuster Company.

Hakim, B. H. 1996. Our bridge to world-class: PT. Caltex Pacific Indonesia's total quality management practice. Training for Quality 4 (1): 40-42.

Harari, O. 1993. The eleventh reason why TQM doesn't work. Management Review 83 (5): 31-35.

Harari, O. 1997. Ten reasons TQM doesn't work. Management Review 86 (1): 37-43.

Howell, R. D. 1987. Covariance structure modeling and measurement issues: A note on interrelations among a channel entity's power sources. Journal of Marketing Research 24 (February): 119-126.

Imai, M. 1986. Kaizen. New York, McGraw-Hill Publishing Company.

Indonesia Business Unit (IBU). 2002. Operational Excellence Implementation: Safety, Environment, Health, Reliability and Efficiency (February). Jakarta, IBU.

Ishikawa, K. 1985. What is Total Quality Control? The Japanese Way. Englewood Cliffs, NJ, Prentice-Hall.

Johnson, R. A., and D. W. Greening. 1999. The effects of corporate governance and institutional ownership types on corporate social performance. Academy of Management Journal 42 (5): 564-576.

Joreskog, K. G., and D. Sorbom, D. 1989. LISREL 7 User's Reference Guide. Chicago: Scientific Software, Inc.

Juran, J. M. 1994. The quality trilogy: A universal approach for managing for quality. In H. Costin (ed.). Total Quality Management. New York: Dryden.

Kolesar, P. J. 1995. Partial quality management: An essay. Journal of Production and Operations Management. 4 (3): 195-200.

Krumwiede, D. W., C. Sheu, and J. Lavelle. 1996. Understanding the relationship of top management personality to TQM implementation. Production and Inventory Management Journal (Second Quarter): 6-10.

Land. 1969. Principles of path analysis. In Borgatta, E., and G. Bohrnstedt (Ed.) Sociological Methodology. San Francisco: Jossey Bass, Inc.

Madu, C. N., and C. Kuei. 1993. Introducing strategic quality management. Long-Range Planning 26 (6): 121-131.

Morgan, N. A., and N. F. Piercy. 1998. Interaction between marketing and quality at the SBU level: Influences and outcomes. Journal of the Academy of Marketing Science 26 (3): 190-208.

Nunnally, J. C. 1967. Psychometric Theory. New York: McGraw-Hill.

Nunally, J. C. 1978. Psychometric Theory. New York: McGraw-Hill.

Pearce II, J. A., and R. B. Robinson, Jr. 2005. Strategic Management: Formulation, Implementation, and Control. ( $9^{\text {th }}$ Ed.). New York, NY. McGraw-Hill. 
Gadjah Mada International Journal of Business, May-August 2005, Vol. 7, No. 2

Russell, L. 1993. Beyond total qualitymanagement. Journal of Quality and Participation 16 (2): 5-10.

Samson, D., and M. Terziovski. 1999. The relationship between total quality management practices and operational performance. Journal of Operations Management 17: 393-409.

Saraph, J. V., P. G. Benson, and R. G. Schroeder. 1989. An instrument for measuring the critical factors of quality management. Decision Sciences 20: 810-829.

Shetty, Y. K. 1993. The quest for quality excellence: Lessons from the Malcolm Baldrige Quality Award. SAM Advanced Management Journal (Spring): 34-40.

Shin, D., J. G. Kalinowski, and G. A. El-Enein. 1998. Critical implementation issues in total quality management. SAM Advanced Management Journal (Winter): 10-14.

Silveira, G. D., and N. Slack. 2001. Exploring the trade-off concept. International Journal of Operation and Production Management 21 (7): 919-964.

Simpson, W. G., and T. Kohers. 2002. The link between corporate social and financial performance: Evidance from the banking industry. Journal of Business Ethics 2 (2) (January): 97-109.

Smith, T. M. and J. S. Reece. 1999. The relationship of strategy, fit, productivity, and business performance in a service setting. Journal of Operations Management 17: 145-161.

Smith A. W., and J. M. Sibler. 1994. TQM success — or it's the process, Stupid! Journal of Property Management (September-October ): 12-16.

Tamimi, N. 1995. An empirical investigation of critical TQM factors using exploratory factor analysis. International Journal of Production Research 33 (11): 3041-3051.

Tamimi, N. 1998. A second-order factor analysis of critical TQM factors. International Journal of Quality Science 3 (1): 71-79.

Tamimi, N., and M. Gershon. 1995. A tool for assessing TQM practice versus the Deming philosophy. Journal of Production and Inventory Management 36 (1): 27 32.

Tamimi, N., M. Gershon, and S. Currall. 1995. Assessing the psychometric properties of Deming's 14 principles. Quality management Journal 2 (3): 38-52.

Tatikonda, L. U. and R. J. Tatikonda. 1996. Top ten reasons your TQM effort is failing to improve profit. Production and Inventory Management Journal (Third Quarter): $5-9$.

The Government of Republic of Indonesia. 2001. Law of the Republic of Indonesia Number 22 Year 2001. Jakarta.

Usilaner, B. 1992. What's the bottom line payback for TQM? The Journal for Quality and Participation 15 (2): 82-90.

Yin, R. K. 2003. Case Study Research: Design and Method. Thousand Oaks, California, Sage Publications, Inc. 
Ciptono-Exploring the Linkages between Deming's Principle, World-Class Company,...

\section{Appendix 1. The Integrative Research Framework: Demonstrated into Mea surement and Structural Components}

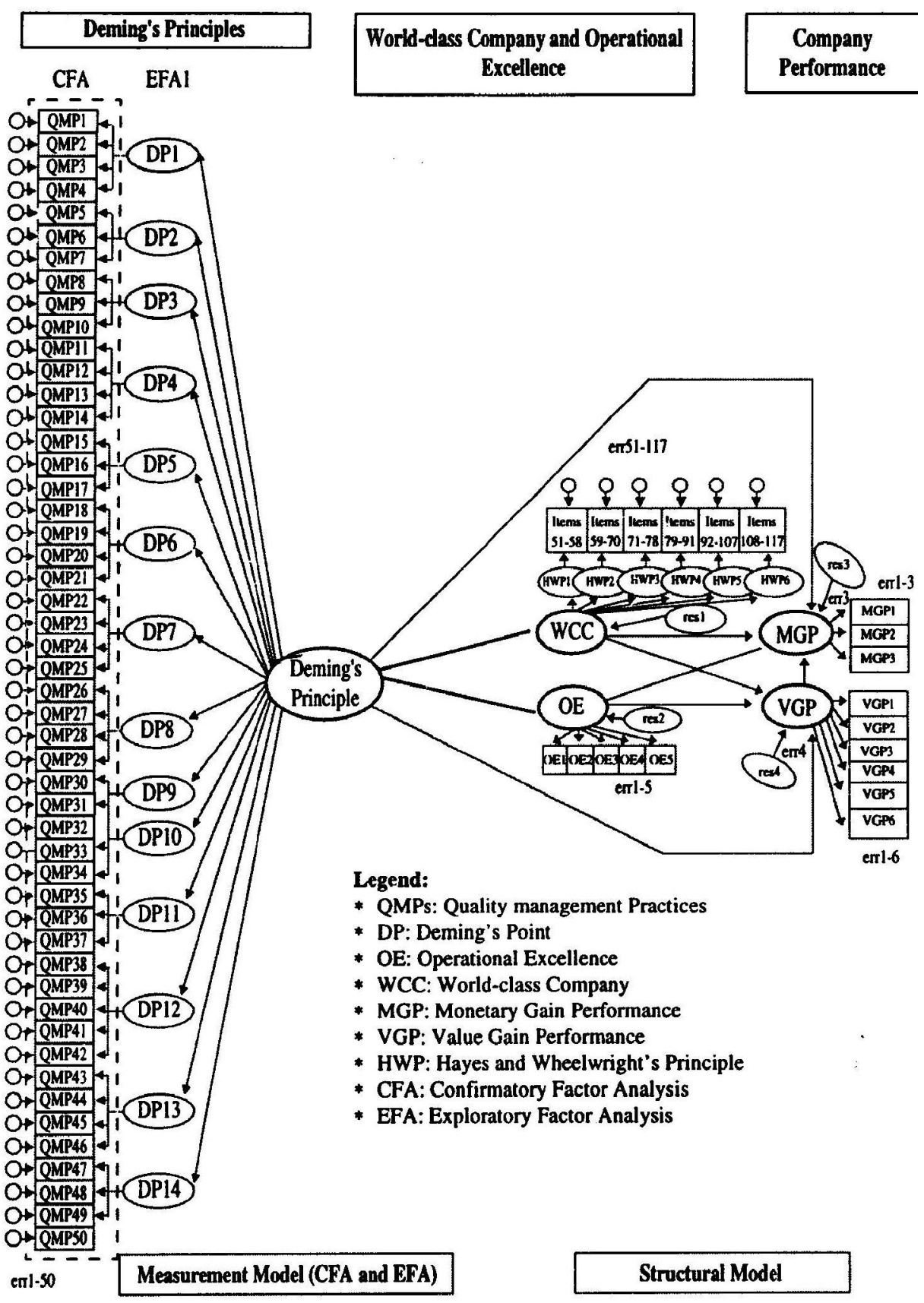


Gadjah Mada International Journal of Business, May-August 2005, Vol. 7, No. 2

Appendix 2. Structural Model (The Initial/Original Model)

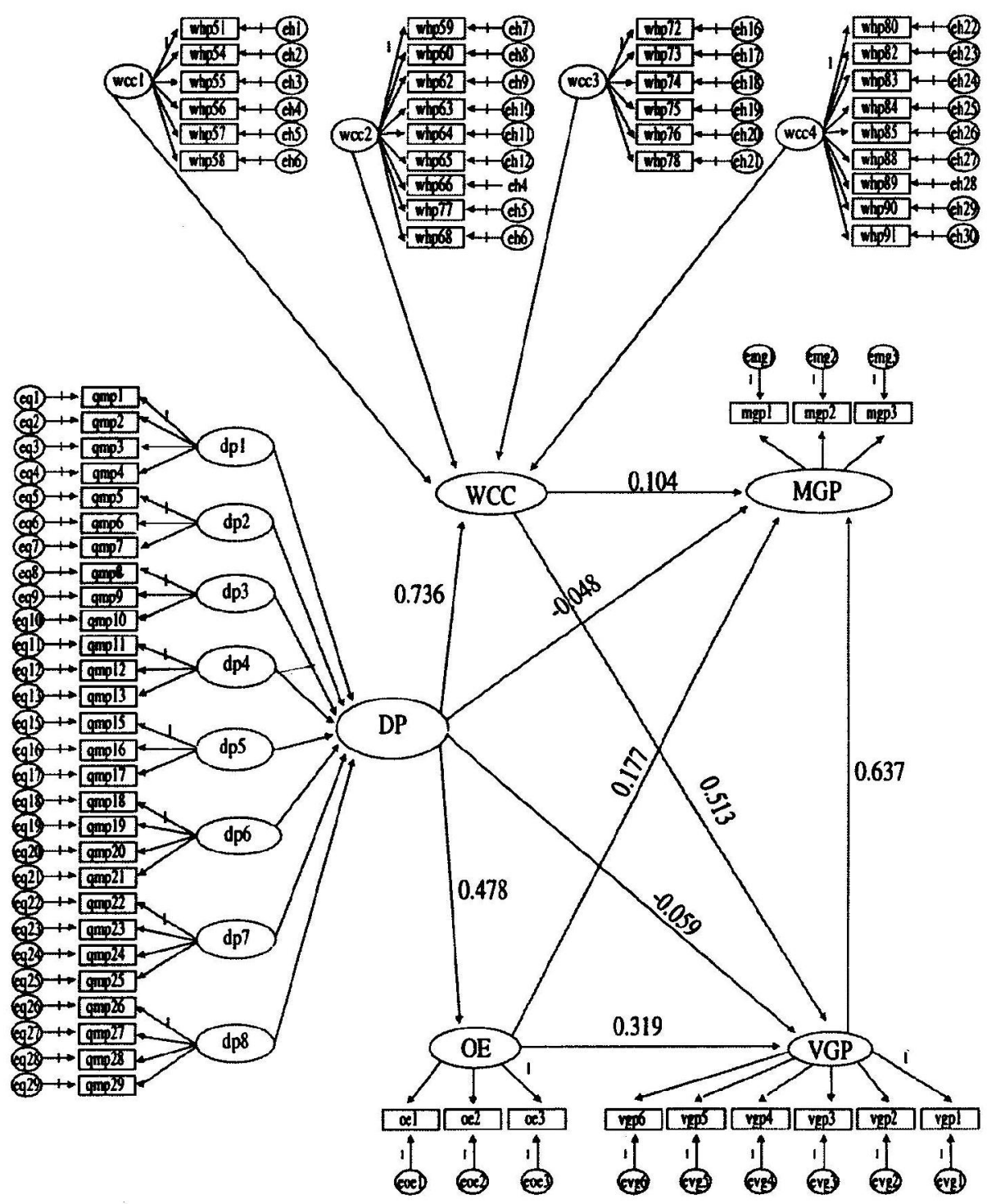


Ciptono-Exploring the Linkages between Deming's Principle, World-Class Company,...

\section{Appendix 3. Structural Model (The Final/Contending Model)}

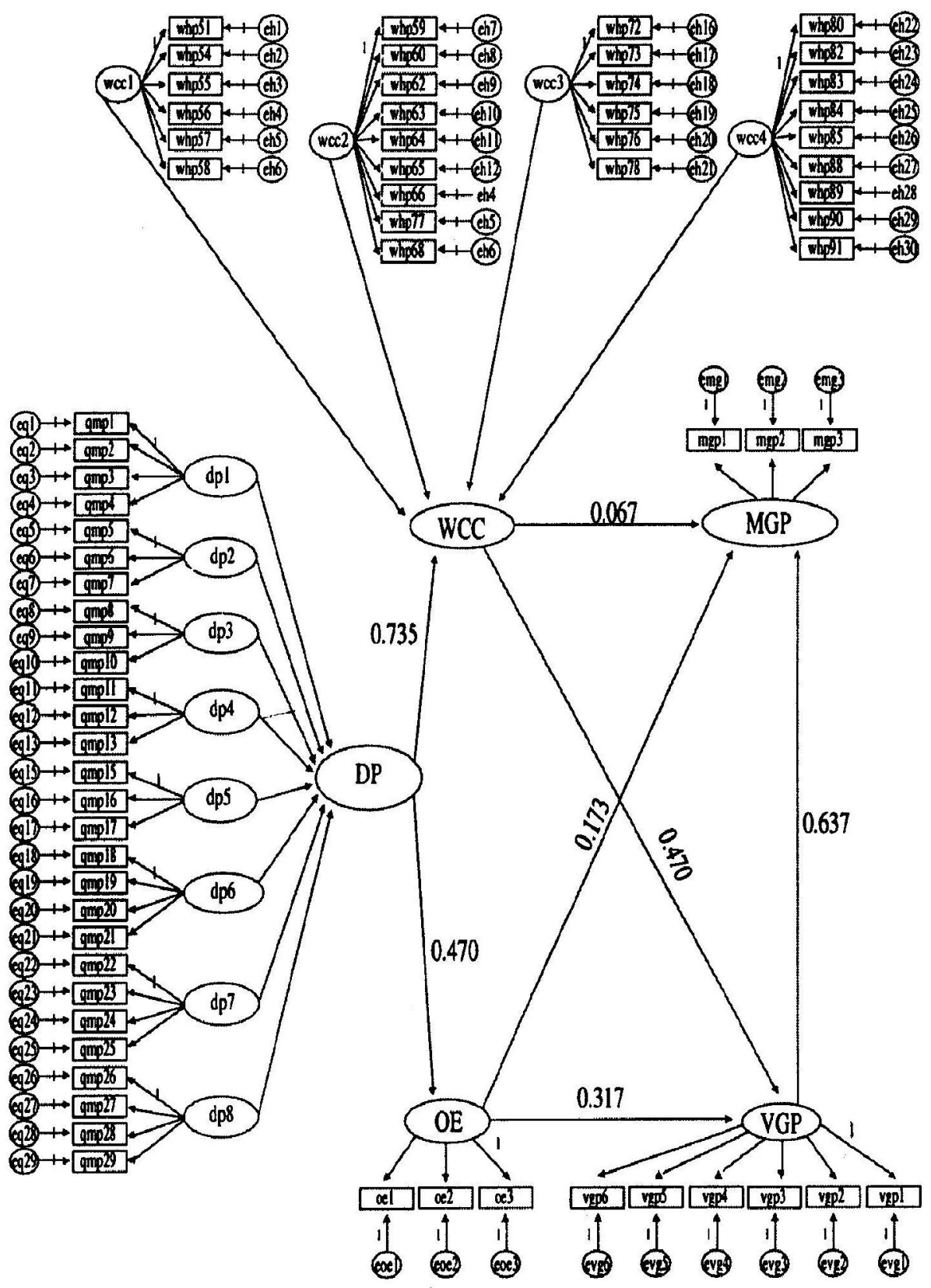

